\title{
Corrosion and Surface Electrochemical Behaviors of Aluminum Alloy 2A12-T3 During Long-Term Exposure at Dry-Hot Climate of Turpan (China)
}

\author{
Ni Li, Chen Man, Junjun Wei, Jizheng Yao, Chaofang Dong* \\ Beijing Advanced Innovation Center for Materials Genome Engineering, Key Laboratory for \\ Corrosion and Protection (MOE), Institute for Advanced Materials and Technology, University of \\ Science and Technology Beijing, Beijing 100083, PR China \\ *E-mail: cfdong@ustb.edu.cn
}

doi: $10.20964 / 2019.02 .40$

Received: 3 November 2018 / Accepted: 4 December 2018 / Published: 5 January 2019

The long-term atmospheric corrosion behaviors of aluminum alloy 2A12-T3 specimens that are exposed in a dry-hot environment for 3 years were investigated via weight loss measurement, electrochemical impedance spectrum (EIS) analysis and several surface analytical techniques. The results demonstrated that the thicknesses of corrosion products that were exposed for 1, 2, and 3 years in Turpan were respectively $2.01 \mu \mathrm{m}, 4.99 \mu \mathrm{m}$ and $7.97 \mu \mathrm{m}$. The average corrosion rate of the 2A12-T3 alloy after exposure for 1,2 and 3 years were $0.62 \mathrm{~g} \cdot \mathrm{m}^{-2} \cdot \mathrm{a}^{-1}, 0.42 \mathrm{~g} \cdot \mathrm{m}^{-2} \cdot \mathrm{a}^{-1}$ and $0.34 \mathrm{~g} \cdot \mathrm{m}^{-2} \cdot \mathrm{a}^{-1}$. With the exposure time extending, the corrosion rate decreased owing to the corrosion products covered on the surfaces. According to the electrochemical measurements, the oxide layer primarily influenced the anodic dissolution process. The corrosion types of the 2A12-T3 alloy are pitting and intergranular corrosion in this environment. The dominate corrosion products were $\mathrm{Al}_{2} \mathrm{O}_{3}$, bayerite $\left(\mathrm{Al}(\mathrm{OH})_{3}\right)$, boehmite $(\mathrm{AlOOH})$ and $\mathrm{AlCl}_{3}$.

Keywords: dry-hot environment; atmospheric corrosion; pitting; intergranular corrosion; 2A12-T3 alloy.

\section{$\underline{\text { FULL TEXT }}$}

(C) 2019 The Authors. Published by ESG (www.electrochemsci.org). This article is an open access article distributed under the terms and conditions of the Creative Commons Attribution license (http://creativecommons.org/licenses/by/4.0/). 